This item was submitted to Loughborough's Research Repository by the author.

Items in Figshare are protected by copyright, with all rights reserved, unless otherwise indicated.

\title{
Determinants of social media adoption by B2B organizations
}

PLEASE CITE THE PUBLISHED VERSION

http://dx.doi.org/10.1016/j.indmarman.2015.05.005

\section{PUBLISHER}

(c) Elsevier

VERSION

AM (Accepted Manuscript)

\section{PUBLISHER STATEMENT}

This work is made available according to the conditions of the Creative Commons Attribution-NonCommercialNoDerivatives 4.0 International (CC BY-NC-ND 4.0) licence. Full details of this licence are available at: https://creativecommons.org/licenses/by-nc-nd/4.0/

\section{LICENCE}

CC BY-NC-ND 4.0

\section{REPOSITORY RECORD}

Siamagka, Nikoletta Theofania, George Christodoulides, Nina Michaelidou, and Aikaterini Valvi. 2019.

"Determinants of Social Media Adoption by B2B Organizations". figshare. https://hdl.handle.net/2134/17138. 


\title{
Determinants of Social Media Adoption by B2B Organizations
}

\author{
Dr Nikoletta-Theofania Siamagka, Kings College London (UK) \\ Prof George Christodoulides*, Birkbeck, University of London (UK) \\ Dr Nina Michaelidou, Loughborough University (UK) \\ Aikaterini Valvi, Birkbeck, University of London (UK)
}

Original submission: 13 December 2013

Resubmission: 9 July 2014

* Corresponding author: Clore Management Building, Birkbeck, University of London, Torrington Square, Bloomsbury WC1E 7HX, London, UK. E: G.Christodoulides@bbk.ac.uk; T: +44 2076316744 


\title{
Determinants of Social Media Adoption by B2B Organizations
}

\author{
Abstract \\ This study contributes to the current dearth of knowledge on the potential of social media as a \\ marketing tool in industrial settings, by focusing on factors that determine social media \\ adoption by B2B organizations. A conceptual model, which draws on the technology \\ acceptance model and resource-based theory, is developed and tested using quantitative data \\ from B2B organizations in the UK. Findings suggest that perceived usefulness of social \\ media within B2B organizational contexts is determined by image, perceived ease of use and \\ perceived barriers. Additionally, the results show that adoption of social media is \\ significantly affected by organizational innovativeness and perceived usefulness. The \\ moderating role of organizational innovativeness is also tested but no support is found. The \\ findings of the study are further validated via nine qualitative interviews with B2B senior \\ managers, yielding additional interesting and in-depth insights into the drivers of social \\ media adoption by B2B organizations.
}

Keywords: Social media, B2B, Adoption, Technology Acceptance Model, Resourcebased theory 


\section{Introduction}

Technological developments have introduced significant changes to the way in which organizations interact with existing and prospective customers. The advent of Web 2.0 technologies and the increased popularity of social media have allowed for a more direct and interactive form of communication, where users can easily share and digest information on the Internet (Akrimi \& Khemakhem, 2012). Individuals tend to spend more time on social networking sites than any other category of site, while 17\% of users' PC time is spent on Facebook alone (Nielsen, 2012).

Appreciating the popularity of social media, organizations are increasing their presence on multiple social media platforms (Michaelidou, Siamagka, \& Christodoulides, 2011). With $26 \%$ of US consumers suggesting that they can accept social networking ads that are based on their profile information (Nielsen, 2012) and consistent with evidence that illustrates the significant benefit of increased reach through brand engagement (Lipsman, Mudd, Rich, \& Bruich, 2012), social networking sites are perceived as a vital marketing tool.

Academic research has largely focused on social media marketing in B2C contexts and has provided insightful evidence regarding the impact of such platforms on consumer purchase decisions (Wang, Yu, \& Wei, 2012), their potential to support brands and collect customer feedback (Breslauer \& Smith, 2009; Christodoulides, 2009) or to provide useful market research data (Nunan \& Yenicioglu, 2013) and generate word-of-mouth (Trusov, Bucklin, \& Pauwels, 2009). Despite their increasing relevance and perceived value in B2B (e-Marketer, 2013) research on the adoption and use of social media channels by B2B organizations is still in its embryonic stage, with only a handful of studies exploring the marketing potential of social media in industrial settings. Although there is some literature on the usage levels, 
barriers and metrics of social media marketing in B2B contexts (e.g. Järvinen, Tollinen, Karjaluoto, \& Jayawardhena, 2012; Michaelidou et al., 2011) little is known regarding the factors that determine social media adoption by B2B organizations. The study draws on previous theory and particularly the Technology Acceptance Model (TAM and TAM2) to investigate social media adoption by B2B firms. However, our study goes beyond the confines of the TAM, which has been criticised by Benbasat and Barki (2007) and Bagozzi (2007), and uses the resource-based theory to identify additional determinants of social media adoption in B2B organisations, such as organizational innovativeness and perceived barriers. Our study contributes to theory in three ways. First, it develops and tests a model to explain social media adoption and appreciate the factors that encourage B2B organizations to utilize social media as part of their marketing activities. Second, it identifies and empirically tests new predictors of adoption, beyond the rubric of the TAM; and, third, it triangulates quantitative findings, with qualitative data from interviews with B2B marketing managers and social media specialists, enhancing understanding of the main determinants of adoption.

The paper opens with a review of existing literature on social media and augments the extended Technology Acceptance Model (TAM2) to identify the key determinants of social media adoption and to develop a model. Following this, the methodology is discussed and results of the quantitative study are presented. The paper then discusses the main findings from the post hoc qualitative study and concludes with research limitations and avenues for future research. 


\section{Literature Review}

\subsection{Social Media}

Social media have attracted significant attention, as scholars and practitioners are eager to understand their potential in supporting brands (Michaelidou et al., 2011; Yan, 2011), sales, customer service, and product development (Culnan, McHugh, \& Zubillaga, 2010).

Consumers perceive social media as more trustworthy than any other information sponsored by organizations and consequently are increasingly turning to social media to get more information about products and services (Foux, 2006). Capitalizing on the popularity of social media and their perceived trustworthiness, more and more organizations have social media presence in order to engage customers with their products and brands (Mangold \& Faulds, 2009).

Empirical evidence suggests that adoption of social media can significantly benefit organizations. In particular, scholarly enquiry indicates that social media can generate higher brand attitudes and purchase intentions than more traditional digital media (Colliander \& Dahlen, 2011). Social media and social networking sites, in particular, have also been used extensively as a marketing communications tool, due to their potential in spreading viral messages (Bampo, Ewing, Mather, Stewart, \& Wallace, 2008) and generating WOM (Trusov et al., 2009). Within organizations, social media have the potential to create capabilities that could translate into useful resources, which in turn result in competitive advantages and higher performance (Lau, 2011; Leonidou, Palihawadana, \& Theodosiou, 2011).

Despite the aforementioned potential of social media and the need for marketing departments to capture the value generated from such channels, marketers tend not to evaluate their effectiveness (Michaelidou et al., 2011). Extant literature suggests that traditional metrics are 
unsuitable for this dynamic and highly interactive environment (Borders, Johnston, \& Rigdon, 2001; Hoffman \& Fodor, 2010), which might explain marketers’ tendency not to assess their effectiveness.

Research on social media use largely focuses on B2C contexts (Michaelidou et al., 2011). It is only recently that empirical investigation has started to address social media marketing in industrial settings. Following from existing evidence that highlights the significant role of the Internet in B2B contexts (Bauer, Grether, \& Leach, 2002; Walters, 2008), B2B researchers have started to appreciate the importance of such tools mainly in attracting new customers and cultivating relationships with existing buyers (Brennan \& Croft, 2012; Michaelidou et al., 2011). This is consistent with established literature on the role of the Internet as a tool that facilitates relationship building. Walters (2008) for example, argues that B2B organizations can implement three-value adding strategies when using the Internet; information rich strategy, relational exchange and joint learning strategy. Consistent with the above evidence, it is apparent that social media marketing is similarly relevant and valuable in B2B contexts as it is in B2C settings, although the rate of adoption has been relatively slower for B2B organizations (Michaelidou et al., 2011).

\subsection{The Technology Acceptance Model (TAM)}

Previous research provides conceptual platforms (e.g. diffusion of innovations, TAM) to investigate technology adoption, pertaining to organizational innovation and environmental characteristics (Davis, 1989; Rogers, 2010; Wamba \& Carter, 2013). However, given that technological innovations differ on fundamental grounds; for example social media is considered more interactive, engaging particularly with regards to communicating with customers and suppliers (Wamba \& Carter, 2013), and less complex compared to other web- 
based applications (e.g. graphics); our scholarly approach to studying such technology seeks to adopt a theoretical platform where constructs are more responsive to empirical operationalization (e.g. TAM) compared to other competing theories (e.g. Porter \& Dunthu, 2006; Rogers, 1995). Our study, therefore, draws on the Technology Acceptance Model (TAM) to investigate social media adoption by B2B organizations, but also addresses criticisms regarding TAM's limited confines by responding to the need for further research focusing on additional predictors (e.g. Bagozzi, 2007; Benbasat \& Barki, 2007).

The TAM was developed by Davis (1989) to predict users' adoption of new technology and has since received immense attention in the academic literature. Relative to other theories and models (e.g. Information Diffusion Theory, Agarwal \& Prasad, 1998a; Moore \& Benbasat, 1991; Rogers, 2010) the TAM is arguably the dominant theory (Bagozzi, 2007; Lee et al., 2003; Venkatesh, Davis, \& Morris, 2007) to predict adoption of technologies. The TAM, which is characterized as parsimonious, has been found to consistently predict a substantial proportion of the variance in technology usage (Bagozzi, 2007; Venkatesh \& Davis, 2000), and "it provides the broadest range of contexts in which generalizability has been examined" (Venkatesh et al., 2007, p268). The model has been applied in multiple technology contexts (e.g. email, voice mail, word possessing, graphics, online shopping etc.) to predict household and organizational usage of technology in both B2B and B2C environments (Adams, Nelson, \& Todd, 1992; Avlonitis \& Panagopoulos, 2005; Ha \& Stoel, 2009; Hernández-Ortega, Jiménez-Martínez, \& Martín-DeHoyos, 2008; Holden \& Karsh, 2010; Hu, Chau, Sheng, \& Tam, 1999; Kim, Lee, \& Law, 2008; Lederer, Maupin, Sena, \& Zhuang, 2000; McKechnie, Winklhofer, \& Ennew, 2006; Pavlou, 2003; Porter \& Donthu, 2006; Venkatesh \& Davis, 2000; Vijayasarathy, 2004). Venkatesh et al. (2007) provide a summary of the research undertaken in the technology adoption field and encourage further research to leverage existing knowledge. We argue that social media is different from other technologies whose 
adoption by B2B organizations has already been examined by TAM, such as sales force automation systems (Jones, Sundaram, \& Chin, 2002), mobile information technology (Lee \& Park, 2008) and CRM software (Avlonits \& Panagopoulos, 2005) because a) social media do not demand such a significant initial investment as in the case of other technologies, b) social media platforms are neither owned by companies nor are they within companies’ control (Christodoulides, 2009), and c) social media content is usually jointly generated by organizations and external stakeholders such as prospective and existing customers (Singh \& Sonnenburg, 2012).

\subsubsection{Perceived Usefulness and Perceived Ease of Use}

The TAM theorizes that perceived usefulness of technology and ease of use predict attitude and usage intention, subsequently leading to adoption and usage of the specific technology. Perceived usefulness is defined as the degree to which one believes that using the technology will enhance his/her performance (Davis, Bagozzi, \& Warshaw, 1992), while perceived ease of use refers to the degree to which one believes that using the technology will be free of effort (Davis et al., 1992; Ha \& Stoel, 2009). Drawing on the Theory of Reasoned Action (Fishbein \& Ajzen, 1975), which emphasizes the influence of external social factors in predicting behavior (e.g. social norms), Venkatesh and Davis (2000) extended the TAM (e.g. TAM2) to include further determinants of perceived usefulness and usage intention. TAM2 does not include attitude towards the technology, but rather, focuses on social influence processes involving image, subjective norm (e.g. Theory of Reasoned Action, Fishbein \& Ajzen, 1975), voluntariness and experience. Consistent with TAM2, later evidence (e.g. Park, 2009; Pentina, Koh, \& Le, 2012) highlighted the impact of social influences on both perceived usefulness and adoption intention. 
In addition, Venkatesh and Davis (2000) added job relevance, quality of output and results demonstrability as key predictors of perceived usefulness and tested their model using mandatory and voluntary technology contexts in four different organizations. The authors' results provided empirical support for TAM2, however, they indicate that subjective norm is a significant predictor of intention to adopt over time only when technology usage is mandatory (Venkatesh \& Davis, 2000). Venkatesh and Davis’s (2000) results across the four organizational contexts show that perceived usefulness was consistently the strongest predictor of intention to use in both mandatory and voluntary technology settings as well as over time. Indeed, perceived usefulness is viewed as the stronger predictor of technology usage or adoption (Chen, Gillenson, \& Sherrell, 2002; Davis, 1989; Koufaris, 2002; Pavlou, 2003; Porter \& Donthu, 2006; Shih, 2004), compared to perceived ease of use in both organizational and consumer contexts and for various technologies including online technologies. For example, Xiao (2010) has found that perceived usefulness explains over $50 \%$ of the variance in online shopping intentions, while perceived ease of use was the strongest predictor of perceived usefulness. Davis (1989) suggests that users' willingness or intention to adopt a new technology is primarily based on perceptions about the usefulness of that technology in conducting the job, and less on whether the technology is perceived as easy or difficult to use. Nevertheless, the literature models both perceived usefulness and ease of use as predictors of new technology adoption. Further, the TAM suggests that perceived ease of use has a significant effect on perceived usefulness. Hence, the easier it is to use a specific technology, the more likely the users will find it useful. Empirical research has provided substantial evidence that supports this relationship in various contexts (e.g. Amin, 2007; Hong, Thong, Wong, \& Tam, 2002; Thong, Hong, \& Tam, 2004), but not in the context of social media. In an attempt to verify this hypothesis in a novel context, we argue that the extent to which B2B organizations find social media easy to use will positively 
impact perceptions of usefulness. On the basis of the aforementioned literature, it is hypothesized that:

H1: Perceived usefulness has a positive impact on social media adoption by B2B organizations.

H2: Perceived ease of use has a positive impact on social media adoption by B2B organizations.

H3: Perceived ease of use has a positive impact on social media perceived usefulness.

\subsubsection{Results Demonstrability and Image}

Further, a number of other key predictors of perceived usefulness have been theorized in the literature (e.g. see Venkatesh \& Davis, 2000) including results demonstrability and image, which are particularly relevant for assessing perceived usefulness of voluntary and also recent technologies such as social media tools. Results demonstrability indicates the extent to which results of using a technology are apparent within an organization, as well as the employees' difficulty in communicating the results to others within an organization (Venkatesh \& Davis, 2000). Similarly, image captures employees’ perceptions about the prestige and status involved in using a specific technology (Venkatesh \& Davis, 2000), which in turn influences perceptions about whether the technology is useful and effective in achieving objectives.

Previous research examining the use of social media tools such as social networking sites (SNS) by B2B organizations (e.g. Michaelidou et al., 2011) reports that $44 \%$ of the B2B organizations surveyed intended to increase their investment in SNS tools. Such a finding indicates that the adoption of social media tools by B2B organizations is perceived as useful 
as it yield results. Similarly, in this study we argue that image is relevant to perceived usefulness of social media as an effective marketing tool. The increased popularity of social media and the established impact on brand image (Bruhn, Shoenmueller, \& Schäfer, 2012) suggest that organizations find these tools useful in terms of image enhancement. Thus, we hypothesize that:

H4: (a) Results Demonstrability, and (b) Image have a positive impact on social media perceived usefulness

\subsubsection{Perceived Barriers and Organizational Innovativeness}

Research has urged scholars to focus on additional predictors of perceived usefulness in an attempt to enhance knowledge and avoid the confines of the TAM (e.g. Benbasat \& Barki, 2007). Hence, additional variables to the existing TAM (and TAM2) are required to predict usage in situations or contexts particularly where users are faced with voluntary choices (Ha \& Stoel, 2009; Vijayasarathy, 2004). Research in this domain has identified additional predictors of perceived usefulness and intention to adopt specifically online technologies. In particular, Porter and Donthu (2006) examined Internet adoption and modeled the relationship between race and income and perceived usefulness associated with Internet usage, with the authors' results indicating that those with lower income perceive Internet usage as less useful. Similarly, Ha and Stoel (2009) applied the TAM on e-shopping identifying trust, and enjoyment as predictors of perceived usefulness. Additional factors such as access barriers (Porter \& Donthu, 2006), compatibility, privacy and security (Vijayasarathy, 2004) have also been identified as predictors of attitude and intention to use online shopping and the Internet. While the application of TAM in the context of the Internet and online shopping is well established, to the authors' best knowledge no research exists 
which examines and models adoption of social media by organizations, despite the fact that the TAM has been immensely applied and replicated foremost in organizational contexts (as opposed to household/consumer contexts) (see Davis et al., 1992; Venkatesh et al., 2007). Recent work in the area of social media usage by B2B organizations (e.g. Michaelidou et al., 2011) has identified a number of barriers to social networking sites (SNS) usage including knowledge, cost and compatibility. In particular, the authors suggest that B2B organizations do not adopt SNS because they view them as unimportant within the industry they operate; identified barriers include uncertainty about how to use SNS to achieve objectives, employee’s lack of knowledge about SNS, and finally the high cost of investment needed to adopt the technology. Such barriers shape perceptions of the usefulness of the technology in achieving organizational objectives, subsequently leading to unwillingness to adopt the technology. On this basis we hypothesize that:

H5: Perceived barriers have a negative impact on the perceived usefulness of social media by $B 2 B$ organizations

Additionally, the resource-based theory of organizations, (e.g. Grant, 1996; Rumelt, 1984; Teece \& Pisano, 1994; Wernerfelt, 1995) suggests that the adoption of technologies is dependent upon an innovative climate within organizations, which fosters new technologies and cultivates specialized knowledge, and which serves to increase the organizations' capabilities. Indeed, resource-based theory can be drawn upon in the context of marketing and technology adoption to emphasize how organizational characteristics or capabilities can contribute towards generating specific forms of customer value (Barney, Wright, \& Ketchen, 2001). In particular, organizational innovativeness, can be seen as a key organizational capability where organizations are open to new ideas and solutions in the context of 
technological adoption (Kunz, Schmitt, \& Meyer, 2011; Wamba \& Carter, 2013). Previous research highlights that more innovative B2B organizations are more likely to adopt new technologies such as social media tools. Michaelidou et al. (2011) found that innovative B2B organizations are more likely to adopt social networking sites such as Facebook, Twitter and Linkedin, while Wamba and Carter, (2013) found that firm innovativeness is positively related to the adoption of Twitter within SMEs. Given that the rate of adoption of social media within B2B organizations is slower than that in B2C contexts (Michaelidou et al. 2011), one may argue that it is predominantly early adopters who champion the adoption in B2B and therefore innovativeness may play a pivotal role in predicting adoption in this context. In line with previous research (e.g. Agarwal \& Prasad, 1998b), we expect organizational innovativeness not only to directly impact adoption but to also moderate the relationships between perceived usefulness/perceived ease of use and adoption. More specifically, the expectation is that higher/(lower) levels of organizational innovativeness will strengthen/(weaken) the aforementioned relationships.

H6: Organizational innovativeness has a positive impact on the adoption of social media by $B 2 B$ organizations.

H7: Higher levels of organizational innovativeness strengthen the relationships between a) perceived usefulness and adoption b) perceived ease of use and adoption of social media by B2B organizations 
Given the dearth of literature in the domain of social media usage by B2B organizations, this study draws on the extended TAM and resource-based theory to develop and empirically test a model for the adoption of social media by B2B organizations. Figure 1 shows the proposed model for the adoption of social media by B2B organizations. The size of the firm (measured by proxy of sales turnover) and the age of the marketing executives in our sample were both inserted as control variables. In line with the literature, we expect companies with more financial resources to be more likely to adopt new technologies (Hall \& Khan, 2002) and younger marketing executives to be more likely to be early adopters and to drive the adoption of social media within their organizations (Hoffman, Novak, \& Schlosser, 2000; LaBay \& Kinnear 1981).

Figure 1: Model for the Adoption of Social Media by B2B Organizations

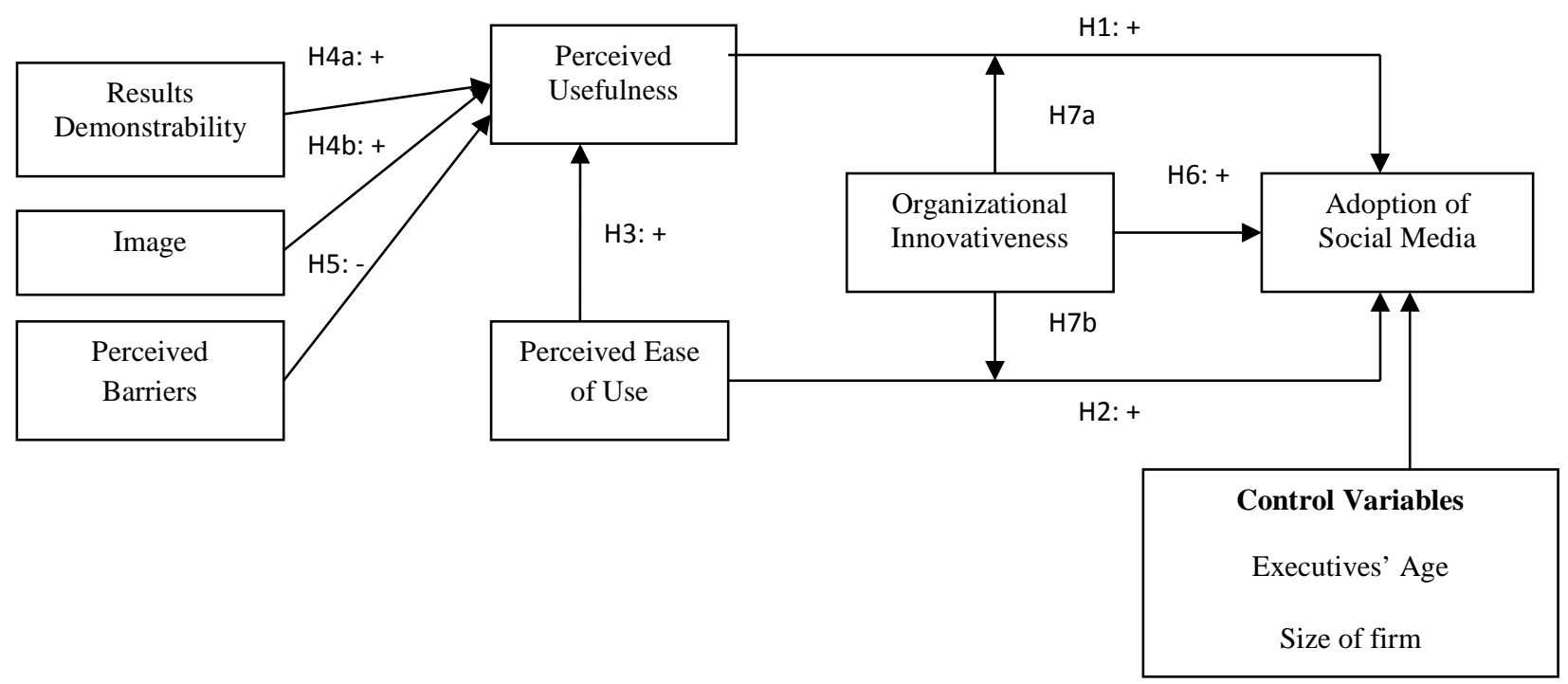

\section{Method}


Data was collected from a sample of 5000 organizations in the UK derived from a permission-based mailing list. A personalized email invitation containing the link to the survey was sent to one senior marketing executive per targeted business. Several industries were represented in the sample (e.g., aerospace, manufacturing, healthcare, etc.). Although 148 fully completed questionnaires were returned (3\% response rate), 105 were retained as these represented B2B organizations. The data was examined for non-response bias in line with Armstrong and Overton's (1977) recommended procedure of comparing early to late respondents. No significant differences emerged between the two groups suggesting that nonresponse bias was not present in the data. The questionnaire consisted of five parts and included measures from TAM2 (Venkatesh \& Davis, 2000), measures of organizational innovativeness (Ellonen, Blomqvist, \& Puumalainen, 2008), perceived barriers (Michaelidou et al., 2011) and adoption of social media. The adoption of social media was measured through a single item on a 7-point scale in line with previous research (e.g. Sila, 2010) ('To what extent does your organization currently use social media?’ 1=not at all/7=very much so). All of the constructs were measured at an organizational level as respondents were clearly instructed to indicate views of the organization they were working for. Regarding results demonstrability, the items reflected the role of the respondent within the organization (i.e. in the items, 'I' reflected their job title within their organizations). Since the target sample consisted of marketing executives in middle/senior positions, we were confident that respondents would be able to reveal the views of the organization. The final part focused on demographic information of the sample. Details of the measures used can be found in Appendix A. The items were measured on 7-point Likert scales (1=strongly disagree, 7= strongly agree). 
In line with the existing literature (Chang, Witteloostuijn, \& Eden, 2010; MacKenzie \& Podsakoff, 2012; Podsakoff, MacKenzie, Lee, \& Podsakoff, 2003), ex-ante procedural remedies were used to limit potential common method bias. Respondents were clearly instructed that there are no right or wrong answers and they were also guaranteed anonymity. The order of the questions was counterbalanced in order for respondents not to be able to identify any possible links between constructs. A statistical, ex post, remedy was also used, where a 'marker' variable was used to compare the structural parameters both with and without this measure to identify the effects on the observed relationships (Lindell \& Whitney, 2001). Consistent with previous research, the second smallest positive correlation was used (Bagozzi, 2011) as a reasonable proxy for common method variance. All coefficients that were significant in a bivariate correlation analysis also remained statistically significant after we controlled for the marker variable. Thus, we can conclude that the results could not be accounted for by common method variance.

\section{Analysis and Findings}

Organizations in the sample varied in terms of their size with an average number of employees of 412 (minimum=4, maximum=5,000). The majority of the marketing executives in the sample held senior positions. In particular, 65 of them were directors or managers. Table 1 summarizes the main characteristics of the B2B organizations represented in the sample.

[Insert Table 1 about here]

\subsection{Trends in Social Media Use by B2B Organizations}


From the companies in the sample, almost $71 \%$ are social media users. Those that have not adopted social media seem to be unsure whether they will do so in the future $(M=4.19$, sd= 2.05). However, almost $42 \%$ have indicated that their companies plan to use social media in the coming year. The most popular social media platform amongst B2B organizations is LinkedIn (67\% of the social media users), while blogs and other social media platforms, such as Pinterest are starting to get the attention of B2B marketing executives. Table 2 summarizes the most common social media platforms utilized by B2B organizations.

[Insert Table 2 about here]

Although most users do not evaluate the effectiveness of their social media marketing activities (57\%), marketing executives seem to appreciate the importance of social media marketing by indicating their intention to increase their investment in such channels ( $44 \%$ of the users). Evidently, social media marketing is now widely recognized for its potential in supporting brands and enhancing brand value.

\subsection{Model Test Results}

Internal consistency reliabilities were first computed for all measures and found to be within acceptable levels, ranging from .76 to .93 (see, Table 3).

[Insert Table 3 about here]

To avoid issues of multicollinearity in our model we followed Little, Bovaird and Widaman's (2006) recommended procedure for orthogonalizing interaction terms and used these 
orthogonalized values in the subsequent analysis. The model was tested on AMOS (version 22.0). Consistent with Anderson and Gerbing (1988), a two-step approach was adopted. Following an acceptable fit of the measurement model $\left(\chi^{2}(266)=399.527\right.$, CFI $=.92$, TLI $=$ .90 , RMSEA $=.06)$, the structural model was then tested and a satisfactory fit was established; $\chi^{2}(308)=462.516(\mathrm{p}<.01), \mathrm{CFI}=.91, \mathrm{TLI}=.90, \mathrm{RMSEA}=.06$. Overall, the model explains $29 \%$ of the variance in the adoption of social media (Table 4).

[Insert Table 4 about here]

The results indicate that perceived usefulness is significantly affected by image $(\beta=.38, \mathrm{p}<$ $.01)$ and perceived barriers $(\beta=-.34, \mathrm{p}<.01)$, confirming $\mathrm{H}_{4 \mathrm{~b}}$ and $\mathrm{H}_{5}$. Our results fail to support the effects of results demonstrability $(\beta=.01, \mathrm{p}>.05)$ on perceived usefulness but interestingly highlight a small negative effect of perceived ease of use on perceived usefulness $(\beta=-.015, \mathrm{p}<.05)$, supporting $\mathrm{H}_{3}$. Our findings indicate that adoption of social media is significantly affected by organizational innovativeness $(\beta=.10, \mathrm{p}<.05)$ and perceived usefulness $(\beta=.17, \mathrm{p}<.01)$, which support $\mathrm{H}_{6}$ and $\mathrm{H}_{1}$. Despite the significant direct effect of organizational innovativeness on adoption, there was no supporting evidence for its moderating role $(\beta=.00, \mathrm{p}>.05$. for Perceived Usefulness X Organizational Innovativeness; $\beta=-.033, \mathrm{p}>.05$ for Perceived Ease of Use X Organizational Innovativeness). H7a and H7b are therefore rejected. Finally, our results fail to provide support to $\mathrm{H}_{2}$, as a non significant relationship between perceived ease of use and adoption of social media is found $(\beta=-.03, \mathrm{p}>$ .05). Age of the marketing executives was also found to be a significant factor that determines adoption $(\beta=.08, \mathrm{p}<.01)$. Contrary to our expectations and conflicting existing research (e.g. Hoffman et al., 2000; LaBay \& Kinnear, 1981), older executives seem to drive the adoption of social media. 


\subsection{Triangulation of findings}

To further enhance the validity of the survey findings through triangulation (Denzin, 1978) and to add richness to their interpretation, nine follow-on semi-structured interviews with B2B marketing managers and social media specialists were undertaken. A purposive sampling technique was used by choosing informants that were in the best position to provide deep insights into the usage of social media by B2B organizations. Table 5 shows the demographic profile of the interviewees.

[Insert Table 5 about here]

The interviews were conducted at a place and time convenient to informants and the average length was 45 minutes. Of the nine interviews, five were conducted face-to-face and four over the phone. All interviews were audio taped and transcribed verbatim. Transcripts were analyzed using template analysis (King, 1998) and codes were developed both a priori based on the literature review, and iteratively as the analysis progressed. Inter-coder reliability was established by two expert academics who independently reviewed the transcripts (coefficient of agreement $=91.8 \%)$. Discrepancies in the coding were resolved through discussion. Appendix B shows representative quotes from the interviews corresponding to each component of the conceptual model. What follows is an integrated discussion that draws on the findings from both the survey and the follow-on interviews.

\section{Discussion}

The study contributes to the limited knowledge about B2B organizations' usage of social media as marketing tools (Michaelidou et al., 2011). Our findings extend existing theories on 
the adoption of new technologies (e.g. TAM2), highlighting the role of perceived barriers and organizational innovativeness in social media adoption by B2B organizations.

Specifically, perceived usefulness, in line with previous research undertaken in other contexts and concerning other technologies (e.g. Davis, 1989; Porter \& Donthu, 2006), was found to be the most significant driver of adoption (in this case of social media by B2B organizations). This was further elaborated in the interviews where the participants identified various benefits stemming from the adoption of social media including enhanced competitiveness, cost-effectiveness, customer engagement/relationship building potential, business exposure and real-time feedback:

“...[I]f you have good content, it means that you can compete effectively with larger companies” (Interviewee 1)

"You can reach over a million people on Facebook if you put a bit of paid media behind it to sponsor the post and boost it and it's actually a very cost effective way of reaching that many people compared to other traditional media forms” (Interviewee 8)

"It [Social Media] gives you insight about your customers. You have the ability to engage customers in real time conversations about your mission, your product, event, or any services that you provide”..... "Social media is very convenient and cost efficient way for augmenting brand visibility. So it allows any business the benefit of increased exposure” (Interviewee 3).

I think it's about opening your eyes as well as to what your customers really think of you as a company. I think that is probably the most beneficial of all the effects that social media can have, because suddenly you are having real time feedback, and you are seeing what people 
really think about you, whilst you know some years ago they may say it to friends in the pub, they are now saying it online, so I think that is the main benefit like knowing what people really think about you and having that direct contact with people (Interviewee 7)

The quantitative study shows that perceived barriers shape perceptions about the usefulness of social media in marketing practices of B2B organizations. Perceived barriers such as cost and uncertainty about the benefits of social media, deter companies from using social media as marketing tools. Further to the survey findings, the qualitative interviews unveiled additional barriers to the adoption of social media by B2B organizations such as consideration of reputational risks and legal issues, lack of staff knowledge/training, senior managers' lack of support, and reluctance to lose control of the brand as shown in the quotes below:

"I would say lack of knowledge, lack of training and can be cost ineffective when you don't know how to use it [social media] are key barriers to adoption” (Interviewee 3)

"There are a lot of legal considerations, and a lot of risks associated with social media... So there is a lot of like, potential issues and conversation needs to be very carefully handled if you have brand exposure” (Interviewee 2)

"A lot of senior leaders within the business actually are of an older generation, and they don't understand it...the fact that they don't understand it means it is very difficult to kind of get a budget signed off, and get approval to do certain things in social and kind of get the buy in from across the organisation that is a really important channel” (Interviewee 8) 
These barriers complement and support previously recognized barriers in the context of B2B SMEs (Michaelidou et al., 2011). Additionally, findings indicate that image shapes perceived usefulness of social media, suggesting that image enhancement efforts are associated with a greater appreciation of social media as effective marketing tools. The interviews reinforced this idea but also pointed out that their misuse and mismanagement may indeed harm this image:

"Image was the original reason for using it [social media], so you have to be, I think in our world, you know you have to be seen to be active on social media, to be taken seriously"

\section{(Interviewee 1)}

"It will definitely enhance the image of the business, but you need to be careful how you use social media to bring out the image of the company which if not being used correctly and efficiently it could destroy the image" (Interviewee 3)

Qualitative data also suggested that social media benefits extend beyond image enhancement and that their adoption by organizations is often driven by a sense of necessity. The perceived pressure from the competitive landscape is such that the non-adoption of social media may in fact detract from the image of the B2B firm:

“If you are not on Facebook somehow you don't exist, so it's beyond image, it is a necessity... you have to engage in certain spaces, because it is expected from your potential clients, so I think there is an image element and definitely it can help you, but... I think many brands have 
been forced to it, without really wanting to, but it was inevitable for them doing so, because they had no alternatives. All their customers were spending more time on Facebook pages of their competitors rather than their own websites, so they had to be there. So I think it is beyond image, I think image is very important, but I think it is much more, even bigger than that, you have to be there, so it is no real choice any more." (Interviewee 2)

Further, the findings complement previous research (e.g. Frambach \& Schillewaert, 2002; Michaelidou et al., 2011) showing that more innovative organizations such as those adopting new technologies and new methods of production and service delivery (relative to their competitors) are more likely to adopt social media in their marketing practices as shown in:

"I think there is a kind of culture internally that if something is new we should try it, which probably helped get the decision [to adopt social media] through” (Interviewee 8).

Contrary to the TAM (Venkatesh \& Davis, 2000), the hypothesized relationships between ease of use and perceived usefulness/adoption were not supported by the survey data. In fact, the data suggested a (statistically significant) negative relationship between ease of use and perceived usefulness. A possible explanation, also supported by the qualitative interviews, is that social media at a theoretical level are considered easy to use. However, using social media more meaningfully for the organization is not so easy and it is perhaps those organizations that understand that a more thoughtful use of social media is actually one that proves more beneficial to their business.

"In terms of the fact that it is easy to use, you press a button, send this update, send that update, it is very easy” (Interviewee 5) 
"I think the basics of social media are really easy to use, I mean everyone has a Facebook account, a twitter, probably many people are on twitter as well, so the basics are easy and easy to understand” (Interviewee 7)

“... all the platforms are so intuitively designed that it is actually very easy to set up and get on with it” (Interviewee 8)

Contrary to our postulation and previous research (e.g. Venkatesh \& Davis, 2000) result demonstrability was also found to be an insignificant predictor of perceived usefulness in the quantitative study. The interviews further clarified the rather complex relationship between results demonstrability and perceived usefulness. Interviewees suggested that social media delivers results in B2B but referred to specific platforms that are more appropriate for this context. They also suggested that the results from social media activities are not necessarily on bottom line measures (such as profit/sales) but on intermediate indicators that, in turn, have an impact on the bottom line:

“LinkedIn works. We tried using Facebook, but we don't see that much engagement on Facebook and interaction, because the people that we need to approach, which are financial managers and directors, won't really spend time on Facebook trying to do stuff there. They will use LinkedIn because it is more professional and serious” (Interviewee 3)

I mean basically for me, before I do anything, whether it is easy or difficult, it's about can it actually, can we get something off this, you know back. It's not so much the whether it's easy or difficult to influence, it is more kind of return on investment and spending some time doing 
that, and we have seen those results from LinkedIn and that is why we are seeing it, the social media stuff as opposed to, we are just doing it because it's easy to do (Interviewee 6)

"When social media is really powerful it is supporting other channels, so what social media is going to do for the business is actually increase the click through rate for search...it is going to increase conversion overall” (Interviewee 7)

The qualitative data suggested an additional factor that may help explain variation in the adoption of social media by B2B organizations. This factor refers to key stakeholders, particularly perceived pressure from buyers and competitors, that ultimately affects B2B organizations' decision to adopt (or not) social media. In the eyes of B2B managers, their prospective and/or existing buyers often expect their suppliers to have social media presence as shown in, "Most of them [our customers] do expect to be able to find us online and many of them are on social media, especially on LinkedIn” (Interviewee 3). Likewise, B2B organizations feel that they have to respond in a similar manner if they perceive their main competitors to employ social media when they do not as seen in: "You see other brands, being successful on social and to be kind of at the forefront of communications and marketing you need to kind of follow suit, so that probably played a factor into the original decision" (Interviewee 8).

\section{Conclusions, Limitations and Future Research}

This study contributes to the limited research on social media in a B2B context by building on previous work (e.g. Michaelidou et al., 2011; Venkatesh \& Davis, 2000) to model 
determinants of social media adoption by B2B organizations. The findings suggest that perceived usefulness and organizational innovativeness are the key drivers for the adoption of social media by B2B organizations whilst perceived ease of use was found to be an insignificant adoption driver in this specific context. Perceived usefulness is, in turn, found to be negatively affected by perceived barriers and positively affected by image enhancement. The results of the post-hoc qualitative interviews with B2B managers also suggest that perceived pressures from key stakeholders (i.e. buyers and competitors) may also influence the adoption decision.

Hence, in addition to its theoretical implications, this study is relevant for B2B organizations that do not currently use social media, but plan to invest in the near future. Our results illustrate that overall B2B companies appreciate the use of social media in enhancing their image, which might suggest that there will be an increase in B2B companies investing in social media. In addition, B2B organizations that have not yet adopted social media for marketing purposes are likely to face increased pressures from prospective and existing buyers who might wish to interact via this platform, and also (indirectly) from competitors who will increasingly use these tools to their advantage. B2B organizations that intend to adopt social media should seek to enhance their managers’ perceptions about the usefulness of social media, and address the perceived barriers through training programs that will enhance employees' skills in social media and identify the importance and relevance of social media within B2B organizations and their industries. B2B organizations that have used social media platforms effectively might also develop case studies focusing on practices adopted to enhance perceptions of usefulness within and across their organizations with the aim of encouraging more organizations to have presence in social media platforms. With regards to training, governmental bodies and trade associations could provide programs designed to 
equip organizations with the necessary skills to overcome the identified barriers and subsequently use social media more widely.

To address the relatively small sample size of our quantitative study a subsequent qualitative study was used as a means to triangulate the survey findings. However, future research should focus on providing quantitative evidence from a larger sample of B2B organizations to allow greater confidence in the results. In addition, our study adopts a deductive approach, where determinants identified through extant literature (e.g. TAM) are tested for their explanatory power regarding social media adoption. Future studies could adopt a more inductive approach, with researchers being more open to new factors that could emerge from a qualitative research design. This could enrich the breadth of determinants of social media adoption within B2B organizations and result in a more comprehensive model that deviates more substantially from the extended TAM, which has been widely applied in different contexts and whose insights are somewhat limited. A further limitation stems from the design of the survey and relates to the instruction to respondents to indicate the views of the organizations they worked for. This technique was adopted in order to identify the organizational factors that determine the adoption of social media. However, even when they were directed to respond to the survey in their professional capacity, our respondents may have still allowed their personal views to affect their responses. To overcome this issue future research may use multiple respondents from the same organization to ensure that the views expressed are indeed shared by the majority of employees. This study considers the extent of social media adoption in general without differentiating between full scale, integrated adoption that suggests a presence in multiple platforms, and a more focused approach, where all the efforts concentrate on one platform. Future research might look into the determinants of adoption for these two different approaches to investigate what drives B2B organizations 
towards a more integrated use of social media. The results of the post-hoc qualitative interviews with B2B managers suggested perceived pressure from key stakeholders to influence B2B organizations’ adoption intention of social media. This as well as other factors should be further tested by means of quantitative research. Finally, our sample is skewed towards small-medium sized organizations. Future research studies should have more large organizations represented in their sample, in order to identify any differences with regards to determinant factors based on company size.

\section{References:}

Adams, D. A., Nelson, R. R., \& Todd, P. A. (1992). Perceived usefulness, ease of use, and usage of information technology: a replication. MIS quarterly, 16(2), 227-247.

Agarwal, R., \& Prasad, J. (1998a). A conceptual and operational definition of personal innovativeness in the domain of information technology. Information systems research, 9(2), 204-215.

Agarwal, R., \& Prasad, J. (1998b). The antecedents and consequents of user perceptions in information technology adoption. Decision support systems, 22(1), 15-29.

Akrimi, Y., \& Khemakhem, R. (2012). What Drive Consumers to Spread the Word in Social Media? Journal of Marketing Research \& Case Studies, 1-14.

Amin, H. (2007). Internet banking adoption among young intellectuals. Journal of Internet Banking and Commerce, 12(3), 1-13.

Anderson, J. C. \& Gerbing, D. W. (1988). Structural equation modeling in practice: A review and recommended two-step approach. Psychological bulletin, 103(3), 411. 
Armstrong, J. S., \& Overton, T. S. (1977). Estimating nonresponse bias in mail surveys. Journal of Marketing Research, 14(8), 396-402.

Avlonitis, G. J., \& Panagopoulos, N. G. (2005). Antecedents and consequences of CRM technology acceptance in the sales force. Industrial Marketing Management, 34(4), 355-368. Bagozzi, R. P. (2007). The Legacy of the Technology Acceptance Model and a Proposal for a Paradigm Shift. Journal of the Association for Information Systems, 8 (4), 243-254.

Bagozzi, R. P. (2011). Measurement and Meaning in Information Systems and Organizational Research: Methodological and Philosophical Foundations. MIS Quarterly, 35(2), 261-292.

Bampo, M., Ewing, M. T., Mather, D. R., Stewart, D., \& Wallace, M. (2008). The effects of the social structure of digital networks on viral marketing performance. Information Systems Research, 19(3), 273-290.

Barney, J., Wright, M., \& Ketchen, D. J. (2001). The resource-based view of the firm: Ten years after 1991. Journal of Management, 27(6), 625-641.

Bauer, H. H., Grether, M., \& Leach, M. (2002). Building customer relations over the Internet. Industrial Marketing Management, 31(2), 155-163.

Benbasat, I., \& Barki, H. (2007). Quo vadis TAM? Journal of the Association for Information Systems, 8(4), 211-218.

Borders, A. L., Johnston, W. J., \& Rigdon, E. E. (2001). Beyond the dyad: electronic commerce and network perspectives in industrial marketing management. Industrial Marketing Management, 30(2), 199-205.

Brennan, R., \& Croft, R. (2012). The use of social media in B2B marketing and branding: An exploratory study. Journal of Customer Behaviour, 11(2), 101-115.

Breslauer, B., \& Smith, T. (2009). Social media trends around the world! The global web index (GWI). ESOMAR Research, Online Research, Chicago. 
Bruhn, M., Schoenmueller, V., \& Schäfer, D. B. (2012). Are social media replacing traditional media in terms of brand equity creation? Management Research Review, 35(9), 770-790.

Chang, S. J., Van Witteloostuijn, A., \& Eden, L. (2010). From the editors: common method variance in international business research. Journal of International Business Studies, 41(2), 178-184.

Chen, L, Gillenson, M. L., \& Sherrell, D. L. (2002). Enticing online consumers: an extended technology acceptance perspective. Information and Management, 39(8), 705-719.

Christodoulides, G. (2009). Branding in the post-internet era. Marketing Theory, 9(1), 141144.

Colliander, J., \& Dahlen, M. (2011). Following the fashionable friend: the power of social media-weighing publicity effectiveness of blogs versus online magazines. Journal of Advertising Research, 51(1), 313-320.

Culnan, M. J., Mchugh, P. J., \& Zubillaga, J. I. (2010). How Large U.S. Companies Can Use Twitter and Other Social Media to Gain Business Value. MIS Quarterly Executive, 9(4), 243260.

Davis, F. D. (1989). Perceived usefulness, perceived ease of use, and user acceptance of information technology. MIS Quarterly, 13(3), 319-39.

Davis, F. D., Bagozzi, R. P., \& Warshaw, P. R. (1992). Extrinsic and intrinsic motivation to use computers in the workplace. Journal of Applied Social Psychology, 22(14), 1111-1132

Denzin, N. K. (1978). The research act: A theoretical introduction to sociological methods. New York: McGraw-Hill. 
e-Marketer (2013). B2B Social Media Lead Generation: Best Practices for 2013. Available at: http://www.emarketer.com/Article/How-B2Bs-Working-Social-Leads/1010162

[Accessed: 9 December 2013]

Ellonen, R., Blomqvist, K., \& Puumalainen, K. (2008). The role of trust in organisational innovativeness. European Journal of Innovation Management, 11(2), 160-181.

Fishbein, M., \& Ajzen, I. (1975). Belief, Attitude, Intention and Behavior: An Introduction to Theory and Research. Reading, MA: Addison-Wesley Publishing Co.

Foux, G. (2006). Consumer-generated media: Get your customers involved. Brand Strategy, 38-39.

Frambach, R. T., \& Schillewaert, N. (2002). Organizational innovation adoption: a multilevel framework of determinants and opportunities for future research. Journal of Business Research, 55(2), 163-176.

Grant, R. M. (1996). Toward a Knowledge-Based Theory of the firm. Strategic Management Journal, 17(S2), 109-122.

Ha, S., \& Stoel, L. (2009). Consumer e-shopping acceptance: Antecedents in a technology acceptance mode. Journal of Business Research, 62(5), 565-571.

Hall, B., \& Khan, B. (2002). Adoption of New Technologies. In: Jones, D. (ed) New Economy Handbook, San Diego, CA: Academic Press Inc.

Hernández-Ortega, B., Jiménez-Martínez, J., \& Martín-DeHoyos, M. J. (2008). Differences between potential, new and experienced e-customers: Analysis of e-purchasing behaviour. Internet Research, 18(3), 248-265.

Hoffman, D. L., \& Fodor, M. (2010). Can you measure the ROI of your social media marketing? MIT Sloan Management Review, 52(1), 41-49. 
Hoffman, D.L., Novak, T.P. \& Schlosser, A.E. (2000). The Evolution of the Digital Divide: How Gaps in Internet Access may Impact Electronic Commerce. Journal of ComputerMediated Communication, 5(3), doi:10.1111/j.1083-6101.2000.tb00341.x

Holden, R. J., \& Karsh, B-T. (2010). The Technology Acceptance Model: Its past and its future in health care. Journal of Biomedical Informatics, 43(1), pp. 159-172.

Hong, W., Thong, J. Y. L., Wong, W. M., \& Tam, K. Y. (2002). Determination of user acceptance of digital libraries: An empirical examination of individual difference and system characteristic. Journal of Management Information System, 18(3), 97-124.

Hu, P. J., Chau, P. Y. K., Sheng, O. R. L., \& Tam, K. Y. (1999). Examining the Technology Acceptance Model Using Physician Acceptance of Telemedicine Technology. Journal of Management Information Systems, 16(2), 91-112.

Järvinen, J., Tollinen, A., Karjaluoto, H., \& Jayawardhena, C. (2012). Digital and social media marketing usage in B2B industrial section. Journal of Marketing Management, 22(2), 102-117

Jones, E., Sundaram, S., \& Chin, W. W. (2002). Factors Leading to Sales Force Automation Use: A Longitudinal Analysis. Journal of Personal Selling and Sales Management, 22(3), 145-156.

Kunz, W., Schmitt, B., \& A. Meyer, A. (2011). How does perceived firm innovativeness affect the consumer? Journal of Business Research, 64(8), 816-822.

Kim, T. G., Lee, J. H., \& Law, R. (2008). An empirical examination of the acceptance behaviour of hotel front office systems: An extended technology acceptance model. Tourism Management, 29(3), 500-513.

King, N. (1998). Template analysis. Symon, G., Cassell, C. (eds.). Qualitative Methods and Analysis in Organizational Research: A Practical Guide. Thousand Oaks, CA: Sage. 
Koufaris, M. (2002). Applying the Technology Acceptance Model and Flow Theory to Online Consumer Behavior. Information Systems Research, 13(2), 205-223.

LaBay, D. G., \& Kinnear, T. C. (1981). Exploring the Consumer Decision Process in the Adoption of Solar Energy Systems. Journal of Consumer Research, 8(3), 271-278.

Lau, C. M. (2011). Team and organizational resources, strategic orientations, and firm performance in a transitional economy. Journal of Business Research, 64(12), 1344-1351.

Lederer, A. L., Maupin, D. J., Sena, M. P., \& Zhuang, Y. (2000). The technology acceptance model and the World Wide Web. Decision Support Systems, 29(3), 269-282.

Lee, Y., Kozar, K.A., \& Larsen K.R.T. (2003). The Technology Acceptance Model: Past, Present, and the Future. Communications of the AIS, 12, 752-780.

Lee, T.M. \& Park, C. (2008). Mobile Technology Usage and B2B Market Performance under Mandatory Adoption. Industrial Marketing Management, 37, 833-840.

Leonidou, L. C., Palihawadana, D., \& Theodosiou, M. (2011). National export-promotion programs as drivers of organizational resources and capabilities: effects on strategy, competitive advantage, and performance. Journal of International Marketing, 19(2), 1-29.

Lindell, M. K., \& Whitney, D. J. 2001. Accounting for common method variance in crosssectional research designs. Journal of Applied Psychology, 86(1), 114-121.

Lipsman, A., Mudd, G., Rich, M., \& Bruich, S. (2012). The Power of "Like": How Brands Reach (and Influence) Fans through Social-Media Marketing. Journal of Advertising Research, 52(1), 40.

Little, T. D., Bovaird, J. A., \& Widaman, K. F. (2006). On the merits of orthogonalizing powered and product terms: Implications for modeling interactions among latent variables. Structural Equation Modeling, 13(4),. 497-519. 
MacKenzie, S. B., \& Podsakoff, P. M. (2012). Common method bias in marketing: causes, mechanisms, and procedural remedies. Journal of Retailing, 88(4), 542-555.

Mangold, W., \& Faulds, D. (2009). Social media: The new hybrid element of the promotion mix. Business Horizons, 52(4), 357-365.

McKechnie, S. Winklhofer, H., \& Ennew, C. (2006). Applying the technology acceptance model to the online retailing of financial services. International Journal of Retail \& Distribution Management, 34(4/5), 388-410.

Michaelidou, N., Siamagka, N. T., \& Christodoulides, G. (2011). Usage, barriers and measurement of social media marketing: An exploratory investigation of small and medium B2B brands. Industrial Marketing Management, 40(7), 1153-1159.

Moore, G. C., \& Benbasat, I. (1991). Development of an instrument to measure the perceptions of adopting an information technology innovation. Information systems research, 2(3), 192-222.

Nielsen (2012). State of the media: The social media report. Available at: http://www.nielsen.com/us/en/reports/2012/state-of-the-media-the-social-media-report2012.html [Accessed 11 December 2013]

Nunan, D., \& Yenicioglu, B. (2013). Informed, uninformed and participative consent in social media research. International Journal of Market Research, 55(6), 791-808

Park, S.Y. (2009). An Analysis of the Technology Acceptance Model in Understanding University Students' Behavioral Intention to Use e-Learning. Educational Technology \& Society, 12(3), 150-162.

Pavlou, P. A. (2003). Consumer Acceptance of Electronic Commerce: Integrating Trust and Risk with the Technology Acceptance Model. International Journal of Electronic Commerce, 7(3), 101-134. 
Pentina, I., Koh, A. C., \& Le, T. T. (2012). Adoption of social networks marketing by SMEs: exploring the role of social influences and experience in technology acceptance. International Journal of Internet Marketing and Advertising, 7(1), 65-82.

Podsakoff, P. M., MacKenzie, S. B., Lee, J. Y., \& Podsakoff, N. P. (2003). Common method biases in behavioral research: a critical review of the literature and recommended remedies. Journal of applied psychology, 88(5), 879.

Porter, C. E., \& Donthu, N. (2006). Using the technology acceptance model to explain how attitudes determine Internet usage: The role of perceived access barriers and demographics. Journal of Business Research, 59(9), 999-1007.

Rogers E. M. (1995). Diffusion of innovations. New York: Free Press.

Rogers, E. M. (2010). Diffusion of innovations. New York: Simon and Schuster.

Rumelt, R. P. (1984). Towards a strategic theory of the firm. Competitive strategic management, 26, 556-570.

Shih, H-P. (2004). Extended technology acceptance model of Internet utilization behavior. Information \& Management, 41(6), 719-729.

Sila, I. (2010). Do organisational and environmental factors moderate the effects of Internetbased interorganisational systems on firm performance? European Journal of Information Systems, 19, 581-600.

Singh, S., \& Sonnenburg, S. (2012). Brand Performances in Social Media. Journal of Interactive Marketing, 26(4), 189-197.

Teece, D., \& Pisano, G. (1994). The dynamic capabilities of firms: an introduction. Industrial and Corporate Change, 3(3), 537-556.

Thong, J. Y. L., Hong, W., \& Tam, K. Y. (2004). What leads to user acceptance of digital 
libraries? Communications of the ACM, 47(11), 79-83.

Trusov, M., Bucklin, R., \& Pauwels, K. (2009). Effects of Word-of-Mouth versus traditional marketing: Findings from an Internet Social Networking Site. Journal of Marketing, 73(5), 90-102.

Venkatesh, V., \& Davis, F. (2000). A Theoretical Extension of the Technology Acceptance Model: Four Longitudinal Field Studies. Management Science, 46(2), 186-204.

Venkatesh, V., Davis, F. D., \& Morris, M. G. (2007). Dead or alive? The development, trajectory and future of technology adoption research. Journal of the Association for Information Systems, 8(4), 267-286.

Vijayasarathy, L. R. (2004). Predicting consumer intentions to use on-line shopping: the case for an augmented technology acceptance model. Information \& Management, 41(6), pp. 747762.

Walters, P. G. (2008). Adding value in global B2B supply chains: Strategic directions and the role of the Internet as a driver of competitive advantage. Industrial Marketing Management, 37(1), 59-68.

Wamba, F., \& Carter, L. (2013). Twitter Adoption and Use by SMEs: An Empirical Study. The 46th Hawaii International Conferences on System Sciences (HICSS), Maui, Hawaii, January 7-10, 2013. Available at SSRN: $\underline{\text { http://ssrn.com/abstract=2137479 }}$ [Accessed: 10 May 2014]

Wang, X., Yu, C., \& Wei, Y. (2012). Social Media Peer Communication and Impacts on Purchase Intentions: A Consumer Socialization Framework. Journal of Interactive Marketing, 26(4), 198-208.

Wernerfelt, B. (1995). The resource-based view of the firm: Ten years after. Strategic Management Journal, 16(3), 171-174. 
Xiao, T. (2010). A cross-national investigation of an extended technology acceptance model in the online shopping context. International Journal of Retail \& Distribution Management, 38(10), 742-759.

Yan, J. (2011). Social media in branding: Fulfilling a need. Journal of Brand Management, 18(9), 688-696. 
Table 1: Characteristics of B2B Organizations

\begin{tabular}{lc}
\hline B2B SMEs Characteristics & $\mathrm{N}(\%)^{1}$ \\
\hline Industry & $58(58)$ \\
Goods & $42(42)$ \\
Services & \\
Size (Sales Turnover) & $9(9)$ \\
$<£ 1 \mathrm{~m}$ & $62(59)$ \\
$£ 1-10 \mathrm{~m}$ & $30(29)$ \\
$£ 11-100 \mathrm{~m}$ & $3(3)$ \\
$£ 101-500 \mathrm{~m}$ & $1(1)$ \\
$£ 501-1 \mathrm{bn}$ & $0(0)$ \\
$£>£ 1 \mathrm{bn}$ & \\
Size (Number of Employees) & \\
$\leq 100$ & $81(77)$ \\
$101<\mathrm{n}<250$ & $15(14)$ \\
$251<\mathrm{n}<500$ & $2(2)$ \\
$\mathrm{n}>500$ & $7(7)$
\end{tabular}

\footnotetext{
${ }^{1}$ Valid percentages used. Percentages might not add up to 100 due to rounding.
} 
Table 2: Social Media Platforms Used by B2B Organizations by Order of Popularity

Social Media Platforms

$\%$ of Social Media Users

\begin{tabular}{clr}
\hline 1. & LinkedIn & 67 \\
2. & Twitter & 62 \\
3. & Facebook & 57 \\
4. & YouTube & 41 \\
5. & Google+ & 26 \\
6. & Others including Blogs, Pinterest, Slideshare etc & 11 \\
7. & MySpace & 2 \\
\hline
\end{tabular}

Table 3: Measures in the Model

\begin{tabular}{lcccc}
\hline & No of Items & & \multicolumn{2}{c}{ Total Sample } \\
\cline { 2 - 5 } & & $\alpha$ & 3.00 & 1.14 \\
\hline $\begin{array}{l}\text { Result Demonstrability (adapted } \\
\text { from Venkatesh \& Davis 2000) }\end{array}$ & 4 & .84 & 3.58 & 1.51 \\
$\begin{array}{l}\text { Image (adapted from Venkatesh \& } \\
\text { Davis 2000) }\end{array}$ & 2 & .93 & 3.81 & 1.24 \\
$\begin{array}{l}\text { Perceived Barriers (adapted from } \\
\text { Michaelidou et al 2011) }\end{array}$ & 5 & .79 & & \\
$\begin{array}{l}\text { Perceived Ease of Use (adapted } \\
\text { from Vankatesh \& Davis 2000) }\end{array}$ & 3 & .79 & 4.96 & 1.18 \\
$\begin{array}{l}\text { Perceived Usefulness (adapted from } \\
\text { Vankatesh \& Davis 2000) }\end{array}$ & 6 & & & \\
$\begin{array}{l}\text { Organizational Innovativeness } \\
\text { (adapted from Ellonen, Blomqvist \& } \\
\text { Puumalainen 2008) }\end{array}$ & 3 & .90 & 3.60 & 1.04 \\
\hline
\end{tabular}


Table 4: Model Path Coefficients and t-values

$$
\begin{aligned}
& \text { Unstandardized t-value p-value } \\
& \text { Coefficients }
\end{aligned}
$$

Effects on Perceived Usefulness $\left(R^{2}=.61\right)$

$$
\begin{aligned}
& \text { H4a: Results Demonstrability } \\
& \text { H4b: Image } \\
& \text { H5: Perceived Barriers } \\
& \text { H3: Perceived Ease of Use }
\end{aligned}
$$$$
.13
$$$$
.38
$$$$
1.81 \quad .071
$$$$
-.34
$$$$
5.81
$$$$
.000
$$

Effects on Adoption $\left(R^{2}=.29\right)$

H1: Perceived Usefulness

H2: Perceived Ease of Use

H6: Organizational Innovativeness

H7a: Perceived Usefulness

Organizational Innovativeness

H7b: Perceived Ease of Use $X$

Organizational Innovativeness

\section{Control Variables}

Age

.08

2.704

.007

Size of firm

$-.06$

$-1.504$ 
Table 5: Interviewees’ Profile

\begin{tabular}{|c|c|c|c|c|}
\hline & Gender & Age & Sector & Job Title \\
\hline 1 & Male & 54 & Business services & Director of Business Development \\
\hline 2 & Male & 29 & Digital Marketing & $\begin{array}{l}\text { EMEA Search and Social } \\
\text { Optimisation Lead, Apps, Media \& } \\
\text { Publishing }\end{array}$ \\
\hline 3 & Female & 34 & Business Software & Digital Marketing manager \\
\hline 4 & Male & 35 & $\begin{array}{l}\text { Distribution and non-resalable } \\
\text { consumer goods }\end{array}$ & $\begin{array}{l}\text { Social Media and Social Intranet } \\
\text { Analyst }\end{array}$ \\
\hline 5 & Male & 25 & Internet B2B networking & Public Relations manager \\
\hline 6 & Male & 31 & Software & Digital Marketing Manager \\
\hline 7 & Female & 31 & B2B Technology & $\begin{array}{l}\text { Global Head of Social Media and } \\
\text { Communities }\end{array}$ \\
\hline 8 & Male & 25 & Financial Services & Marketing manager \\
\hline 9 & Female & 34 & $\begin{array}{l}\text { Public sector, holistic marketing, } \\
\text { leisure, commercial and corporate }\end{array}$ & Director \& Marketing Consultant \\
\hline
\end{tabular}




\section{Appendix A}

Result Demonstrability ${ }^{2}$ (adapted

from Venkatesh \& Davis 2000)

Image (adapted from Venkatesh \&

Davis 2000)

Perceived Barriers (adapted from

Michaelidou et al 2011)

Perceived Ease of Use (adapted

from Vankatesh \& Davis 2000)

Perceived Usefulness (adapted

from Vankatesh \& Davis 2000)
1. I have no difficulty telling others about the results of using (or not using) social media for our business.

2. I believe I could communicate to others the consequences of using (or not using) social media for our business.

3. The results of using (or not using) social media are apparent to me.

4. I would have difficulty explaining why using (or not using) social media may or may not be beneficial to our company

1. Companies who use social media have a better image than those who do not.

2. Companies who use social media are better regarded by customers.

1. Social media are a big investment.

2. Our staff are not familiar with them.

3. Our staff do not have the technical skills to use them.

4. We are unsure whether/how social media can help our company.

5. The costs of social media outweigh the potential benefits for our company.

1. It is difficult to use social media.

2. Social media are unclear and not understandable.

3. Interacting via social media requires a lot of mental effort.

1. Using social media improves business performance.

2. Using social media increases business productivity.

3. Using social media enhances effectiveness in business.

\footnotetext{
${ }^{2}$ I denotes the job title within a specific organization. E.g. "I, as Marketing Director in XYZ company, have no difficulty telling others about the results of using (or not using) social media for our business".
} 
4. Social media are useful for businesses.

5. Social media have a strong impact on any business.

6. Using social media increases problem solving capability

Organizational Innovativeness

(adapted from Ellonen, Blomqvist

\& Puumalainen 2008)
1. In comparison with its competitors, my organization has become much more innovative.

2. During the past five years, my organization has developed many new management approaches.

3. My organization improves its business processes constantly. 
Appendix B 
Quotes

Coding

- ...[I]f you have good content, it means that you can compete effectively with larger companies (Interviewee 1)

- ...that is why I use it because as a small company it makes me look bigger than I am in some ways. It increased your global reach because you can still be the person to person talking conversation, as though you were getting the highest networking joint, that is kind of the value in it (Interviewee 9)

- It's a more cost effective form of marketing for us, I mean we are small, we are in a specialist area, we have a particular niche, and reaching out to people in that niche, is better done through social media (Interviewee 1) - In social media, it is very convenient and cost efficient way for augmenting brand visibility. So it allows any business the benefit of increased exposure (Interviewee 3)

- You can reach over a million people on Facebook if you put a bit of paid media behind it to sponsor the post and boost it and it's actually a very cost effective way of reaching that many people compared to other traditional media forms (Interviewee 8)

- You can engage with customers, you can understand your audience; you can be relevant with your brand and be much more effective when you are promoting content or products, so it's a better way to engage potential clients

\section{(Interviewee 2)}

- It [social media] gives you insight about your customers. You have the ability to engage customers in real time conversations about your mission, your product, event, or any services that you provide...(Interviewee 3)

- It's a way to build a better relationship with your customer..., but also the kind of guest broadcast, reach and engagement you can get (Interviewee 8)

- I think the main one is literally engaging with your customers, that has to be the pinnacle of it (Interviewee 8) - Social media can actually help you put a personal face on your business, so instead of just the company name, customers see you as a real person who listens to their concerns and delivers helpful feedback. So this is where the quality of your social media really matters (Interviewee 3)

- I think it's about opening your eyes as well as to what your customers really think of you as a company. I think that is probably the most beneficial of all the effects that social media can have, because suddenly you are having real time feedback, and you are seeing what people really think about you, whilst you know some years ago they may say it to friends in the pub, they are now saying it online, so I think that is the main benefit like knowing what people really think about you and having that direct contact with people (Interviewee 7)

- Everybody can use social media (Interviewee 1)

- Social media being so successful thanks to how easy they are to be used... So the way it was built originally and stil is most of like the two main social networks, Facebook and Twitter are extremely simple. The only thing you have to do is write what you are thinking and what you are doing and they try to make these extremely simple for any user from 70 year old to 6 years old. (Interviewee 2 )

\begin{tabular}{|c|c|}
\hline Meta-code & Code \\
\hline \multirow{4}{*}{$\begin{array}{l}\text { Perceived } \\
\text { Usefulness }\end{array}$} & $\begin{array}{c}\text { Effective } \\
\text { Competitiveness }\end{array}$ \\
\hline & Cost Effectiveness \\
\hline & $\begin{array}{c}\text { Customer } \\
\text { Engagement }\end{array}$ \\
\hline & Direct Feedback \\
\hline
\end{tabular}


- In terms of the fact that it is easy to use, you press a button send this update, send that update, it is very easy (Interviewee 5)

- ... all the platforms are so intuitively designed that it is actually very easy to set up and get on with it (Interviewee 8)

- I think there is a kind of culture internally that if something is new we should try it, which probably helped get the decision [to adopt social media] through (Interviewee 8)

- I wouldn't say I use social media to be innovative, my company isn't like that ... I don't think social media is being very innovative any more (Interviewee 9)

- There are a lot of legal considerations, and a lot of risks associated with social media... So there is a lot of like, potential issues and conversation needs to be very carefully handled if you have brand exposure, so if there are some privacy concerns (Interviewee 2)

- ...for any business there are some risks around the way you engage on social networks... the more you put out in terms of content and information, the more risks you have. If you are on like a Facebook page on which you are promoting your brand, you are going to have less issues than if you are constantly sending out information about stories and news and those sort of things (Interviewee 2)

- I would say lack of knowledge, lack of training and it can be cost ineffective when you don't know how to use it (Interviewee 3)

- The main barriers, I honestly think it's probably an internal stakeholder management piece, because a lot of senior leaders within the business actually are of an older generation, and they don't understand it...the fact that they don't understand it means it is very difficult to kind of get budget sign off, and get approval to do certain things in social and kind of get the buy in from across the organisation that is a really important channel. I think that is the main issue that faces (Interviewee 8)

- There is a big issue about giving staff the responsibility to manage social media (Interviewee 1)

- Control, I think, is the central barrier (Interviewee 9)

\section{Org. Innovativeness}

\begin{tabular}{l|l} 
& $\begin{array}{l}\text { Lack of support } \\
\text { from senior } \\
\text { management }\end{array}$ \\
\hline Image was the original reason for doing it, so you have to be, I think in our world, you know you have to be seen to & Loss of control \\
\hline \\
\hline
\end{tabular}


media to bring out the image of the company which if not being used correctly and efficiently it could destroy the image (Interviewee 3)

- ...it [social media use] is all based on reputation and image (Interviewee 5)

- We need to kind of be there, we need to be trying things and if it doesn't work it doesn't work, if it works fantastic. I think, yes we need to, I think image is part of it, but I think also business benefit is like an equal if not more important part (Interviewee 6)

- If you are not on Facebook somehow you don't exist, so it's beyond image, it is a necessity... you have to engage in certain spaces, because it is expected from your potential clients, so I think there is an image element and definitely it can help you, but... I think many brands have been forced to it, without really wanting to, but it was inevitable for them doing so, because they had no alternatives. All their customers were spending more time on Facebook pages of their competitors rather than their own websites, so they had to be there. it is much more, even bigger it is much more, even bigger (Interviewee 2)

- We need to kind of be there, we need to be trying things and if it doesn't work it doesn't work, if it works fantastic. I think, yes we need to, I think image is part of it, but I think also business benefit is like an equal if not more important part (Interviewee 6)

- It was definitely a necessity, social media is needed to be part of what we do, because that is how our clients connect, how we can actually add value to our business, so it was about adding value to you know, to be reachable, to be providing the right advice, to have access directly to us, to you know appear more human as well because this is not just about a faceless operation it is about the people behind it. So it's more about what we want to be and what we have to be as well (Interviewee 7)

- LinkedIn works. We tried using Facebook, but we don't see that much engagement on Facebook and interaction, because the people that we need to approach, which are financial managers and directors, won't really spend time on Facebook trying to do stuff there. They will use LinkedIn because it is more professional and serious (Interviewee 3)

- I mean basically for me, before I do anything, whether it is easy or difficult, it's about can it actually, can we get something off this, you know back. It's not so much the whether it's easy or difficult to influence, it is more kind of return on investment and spending some time doing that, and we have seen those results from LinkedIn and that is why we are seeing it, the social media stuff, we are just doing it because it's easy to do (Interviewee 6)

- When social media is really powerful it is supporting other channels, so what social media is going to do for the business is actually increase the click through rate for search...it is going to increase conversion overall, so when we send an email to people with an offer, they already trust us, they already have a relationship with us, so they are more likely to actually click on the offer and get it, the same when they are searching for us, so they may have interaction with us on Facebook, on Twitter or in our blog, but they are not going to buy at that moment because they are looking for proof... but when it comes to, you know making a decision about buying a website, or getting our platform they are just going to search for us, so that is when we get the return on investment (Interviewee 7)

- I think even if we weren't so innovative we would still have to adopt it [social media], because that is you know, that is the kind of competitive landscape now (Interviewee 1)

- The competitors are on social media, so that is one reason good enough to be there as well (Interviewee 3)

- You see other brands, being successful on social and to be kind of at the forefront of communications and marketing

Results Demonstrability

Stakeholders

Pressure from

competitors 
you need to kind of follow suit, so that probably played a factor into the original decision... When a competitor does something we wonder why we are not doing it, so we just go ahead and make sure so we are covered basically

\section{(Interviewee 8)}

- Most of them [buyers] do expect to be able to find us online and many of them are on social media, especially on LinkedIn. (Interviewee 3)

- One of the biggest things I talk about is the consumerization of B2B and that expectation of, from consumers, who also have jobs, that their experience at work should be as good as their experience from home. So using Tesco,

Amazon, they expect the same experience when they are using a B2B website to buy something. And in the same breath they expect, or they are accepting of B2B being on social (Interviewee 4)

- ...you are expected to have a presence there [on social media], you are expected to answer if someone gets to you, but you are not necessarily expected to be proactive with it (Interviewee 5)

- I think there is an expectation that companies are on social media today, and that they are providing the latest kind of relevant news to their customers through, especially Twitter, and seeing if there is any system outages, or problems, people will expect that to be announced on Twitter, so that they have the latest up to date information and we have actually seen where we haven't announced it people will go on Twitter to complain about that. (Interviewee 8) 